\title{
EFFECT OF HONEY BEE ON SOME ANTIOXIDANT ENZYMES AND LIPID PROFILE IN HYPERCHOLESTEROLEMIC MALE ALBINO RATS
}

\author{
Aziza A.M. El-Shafey; Moshira M.E. Seliem; Safaa A.M. El-Zawahry; Eman M.S. Shahen and Doaa \\ E.M. Mahmoud \\ Zoology Department, Faculty of Science, Benha University, Benha, Egypt.
}

\begin{abstract}
The present study investigates the effect of administration of honey bee on serum antioxidant enzymes "catalase, superoxide dismutase (SOD) and glutathione peroxidase (GPx)" and lipid profile in hypercholesterolemic male albino rats. Eighty four male albino rats weighting $150 \pm 20 \mathrm{~g}$ were divided into six groups as follows: control group (freely supplemented with standard diet), coconut oil treated group ( 0.5 $\mathrm{ml}$ daily), cholesterol treated group ( $400 \mathrm{mg} / \mathrm{kg} \mathrm{b.w} \mathrm{dissolved} \mathrm{in} 0.5 \mathrm{ml}$ coconut oil), honey treated group (1 $\mathrm{ml} / \mathrm{rat}$ of $20 \%$ honey bee), cholesterol and honey treated group and cholesterol before honey treated group. All treatments were by oral administration for two months. The results showed that, after one and two months coconut oil treated group showed significant increases in catalase and high density lipoprotein cholesterol (HDL-C) and significant decrease in low density lipoprotein cholesterol (LDL-C), while GPx significantly increased after two months. Treatment with cholesterol for one and two months caused significant decreases in antioxidant enzymes and significant increases in total cholesterol "TC" and LDL-C, while total lipid (TL), triglyceride (TG) and very low density lipoprotein cholesterol (VLDL-C) were significantly increased after two months. After one and two months, honey bee treated group showed significant increases in antioxidant enzymes and HDL-C and significant decreases in TG, LDL-C and VLDL-C, while TL was significantly decreased after two months. After one and two months, cholesterol and honey and cholesterol before honey treated groups showed non significant changes in antioxidant enzymes while these groups showed significant increases and decreases in HDL-C and LDL-C respectively. These results indicated that honey administration with or after cholesterol treatment acted for ameliorating the disturbances in antioxidant enzymes and lipid profile that induced by hypercholesterolemia. Honey bee administration for two months is more effective than one month in return of most measured parameters to about control values.
\end{abstract}

Key words: honey bee, hypercholesterolemia, antioxidant enzymes, lipid profile.

\section{INTRODUCTION}

$\mathbf{H}$ ypercholesterolemia is a causal factor of atherosclerosis, a process histologically characterized by lesions processing from fatty streaks to fibrous plaques, ultimately occludes the lumen of the affected artery ${ }^{(\mathbf{1}, 2)}$. However, chronic elevation in serum cholesterol was often associated with an impaired endotheliumdependent vasodilation ${ }^{(3)}$.

Several reports showed that hypercholesterolemia diminishes the antioxidant defense system and decreases the activities of superoxide dismutase (SOD) and catalase (CAT) and elevating the lipid peroxide content ${ }^{(4)}$.

Heibashy (5) found that there were significant increases in total serum cholesterol, total lipids, triglycerides, VLDL-C and LDL-C in cholesterol-fed rats. Salem and Zaahkouk ${ }^{(\boldsymbol{(})}$ also reported that hypercholesterolemic rats showed significant increases in serum total lipid, TC, albumin, uric acid and glucose.

Nevin and Rajamohan ${ }^{(7)}$ found that rats which fed on diet contain virgin coconut oil showed decreases in serum TC, TG, LDL-C and
VLDL-C levels but there was an increase in HDLC.

Many complications have been attributed to oxidative damage, including atherosclerosis, aging, and cancerous diseases. Antioxidant foods that are rich in flavonoids are protective agents against these ailments ${ }^{(8)}$. Honey bee contains a variety of biologically active compounds such as flavonoids, vitamins, antioxidants as well as hydrogen peroxides $\left(\mathrm{H}_{2} \mathrm{O}_{2}\right)^{(9)}$.

Honey occupied important role in the traditional medicine over 4000 years ago ${ }^{(\mathbf{1 0}, \mathbf{1 1})}$. Honey provides antibacterial, anti-inflammatory, immune-stimulant, antiulcer and wound/burn healing (regenerative) effects ${ }^{(\mathbf{1 2})}$.

Antioxidants in honey have also been implicated in reducing the damage done to the colon in colitis ${ }^{(\mathbf{1 3})}$. Honey intoxication is more likely when using "natural" unprocessed honey and honey from farmers who may have a small number of hives. Commercial processing, with pooling of honey from numerous sources generally dilutes any toxins ${ }^{(\mathbf{1 4})}$.

On the other hand, Omotayo et al. ${ }^{(15)}$ found that honey significantly increased total 
antioxidant status, activities of catalase (CAT), glutathione peroxidase $(\mathrm{GPx})$, glutathione reductase (GR), and glutathione-S-transferase (GST) in diabetic rats.

Also, honey intake decreases body weight, total cholesterol, low-density lipoproteincholesterol and triglyceride, while high-density lipoprotein-cholesterol increased significantly ${ }^{\left({ }^{(16)}\right.}$.

Luka et al. ${ }^{(17)}$ found that feeding honey solution to rats increased their serum HDL-C concentration while the serum LDL-C concentration decreased. Honey intake decreased plasma cholesterol and LDL-C and increased HDL-C, VLDL-C and triglycerides in albino rats (18)

In a recent study, metformin (anti-diabetic drug) combined with Ilam honey markedly produced lower levels of hyperglycemia, bilirubin, triglycerides, total cholesterol, VLDL and LDL and increased high density lipoprotein (HDL) cholesterol. On the other hand, metformin alone neither reduced bilirubin and triglycerides nor increased HDL in diabetic rats ${ }^{(\mathbf{1 9})}$.

Abdulrhman et al. ${ }^{(20)}$ reported that honey administration improved glycemia, lipid profile and adiposity in type 1 diabetic patients.

The combination of gelam honey and ginger did not show hypoglycaemic potential; however, the combination treatment reduced significantly SOD and CAT activities, while reduced glutathione (GSH) level was significantly elevated in STZ-induced diabetic rats compared to diabetic rats ${ }^{(21)}$.

Samat et al. ${ }^{(22)}$ found that both male and female rats fed with gelam honey $(\mathrm{GH})$ displayed a significant decrease in triglycerides compared to control group.

Therefore the present study undertaken the effect of honey administration on antioxidant enzymes and lipid profile in hypercholesterolemic male rats after one and two months.

\section{MATERIAL AND METHODS}

\section{-Experimental Animals:}

Eighty four male albino rats (western strain) weighting $150 \pm 20 \mathrm{~g}$ were used in the present study. The animals were obtained from Veterinary Serum and Vaccine Research Institute, Abbasia, Cairo, Egypt. Rats were housed in stainless steel wire bottom cages, kept under constant environmental conditions $\left(25 \pm 2^{\circ} \mathrm{C}\right.$ and $12 \mathrm{~h}$ dark/light cycle), fed on fresh standard pellet and given tap water ad libitum throughout the study. All animals were acclimatized for 1 week before the beginning of the experiment.

-Cholesterol and Honey:
- Cholesterol, white crystalline powder was obtained from Middle East Company for Medical and Scientific Apparatus Laboratory Equipments and Chemicals, Cairo, Egypt. For cholesterol administration, it was dissolved in coconut oil. Daily oral dose of cholesterol was administrated for the experimental rats as described by Dubey $\boldsymbol{e t}$ al., ${ }^{(23)}$. Coconut oil was obtained from pyramid Company for New Industry, Cairo, Egypt.

- Commercially processed honey was obtained from Egyptian beekeeping farmer. The honey used in this study called flower clover honey, gathered in May to mid-June. Daily oral dose of honey was administrated for the experimental rats as described by Syazana et al., ${ }^{(24)}$.

\section{- Experimental design:}

Animals were divided into six groups (14 rats each):

- The first group: (control group). Normal untreated rats (-ve control).

.The second group: (coconut oil group). Rats administrated a daily oral dose of coconut oil (0.5 ml) (+ve control).

.The third group: (cholesterol group). Rats administrated a daily oral dose of cholesterol \{400 $\mathrm{mg} / \mathrm{kg} \mathrm{b} . \mathrm{w}$ \} dissolved in $0.5 \mathrm{ml}$ coconut oil.

.The fourth group: (honey group). Rats administrated a daily oral dose of $20 \%$ honey $\{1$ $\mathrm{ml} / \mathrm{rat}\}$.

.The fifth group: (cholesterol and honey group). Rats administrated a daily oral dose of $20 \%$ honey $\{1 \mathrm{ml} / \mathrm{rat}\}$ with a daily oral dose of cholesterol $\{400 \mathrm{mg} / \mathrm{kg}$ b.w dissolved in $0.5 \mathrm{ml}$ coconut oil\}.

Each of these five groups was subdivided into two sub groups. one used after one month and the other used after two months of the experimental period.

.The six group: (cholesterol before honey group). Rats divided into two sub groups:

1- The first half of rats administrated a daily oral dose of cholesterol $\{400 \mathrm{mg} / \mathrm{kg}$ b.w dissolved in $0.5 \mathrm{ml}$ coconut oil $\}$ for 20 days then administrated a daily oral dose of $20 \%$ honey $\{1 \mathrm{ml} / \mathrm{rat}\}$ for 10 days.

2- The second half of rats administrated a daily oral dose of cholesterol $\{400 \mathrm{mg} / \mathrm{kg}$ b.w dissolved in $0.5 \mathrm{ml}$ coconut oil $\}$ for 40 days then administrated a daily oral dose of $20 \%$ honey $\{1$ $\mathrm{ml} / \mathrm{rat}\}$ for 20 days. All administrations were given by gastric tube.

\section{-Blood samples:}

Blood samples were collected from the heart of seven rats of each group after the end of both $1^{\text {st }}$ and $2^{\text {nd }}$ months of the experimental period in small dry tubes and centrifuged at $3000 \mathrm{rpm}$ for 
15 minutes. Then sera were separated and stored at $-20^{\circ} \mathrm{C}$ until biochemical analysis.

\section{-Biochemical Analysis}

Serum catalase, superoxide dismutase and glutathione peroxidase activities were determined according to the methods of Luck ${ }^{(25)}$, Kakkar $\boldsymbol{e t}$ al. ${ }^{(26)}$ and Reddy et al. $^{(27)}$ respectively.

Serum total lipid (TL) was determined according to the method of Zolliner and Kirsch (28), using Biodiagnostic kit. Serum triglyceride (TG) concentration was determined according to the method of Trinder ${ }^{(29)}$ using Sgmitalia kit. Total cholesterol (TC) concentration was determined according to the method of Meiattini et al. ${ }^{(30)}$ using Spinreact kit. High density lipoprotein- cholesterol (HDL-C) concentration was determined according to the method of Friedewald et al. ${ }^{\left({ }^{(3)}\right.}$ using Spectrum kit. All parameters were determined spectrophotometerically.

Calculation of LDL-C and VLDL- C (mg/dl)

Concentrations of LDL-C and VLDL-C are usually calculated by the equation of Friedewald et al. ${ }^{(31)}$ as follows:

$$
\begin{aligned}
& \text { LDL-C }=\mathrm{TC}-(\text { HDL-C })-\text { VLDL } \\
& \text { VLDL-C }=\mathrm{TG} / 5
\end{aligned}
$$

\section{-Statistical Analysis:}

The values of measured and calculated parameters were expressed as the mean of 7 individual values \pm standard error "SE". Statistical analysis carried out using one way analysis of variance (ANOVA) and Least significant difference $(L S D)$ at $(p<0.05)$ was calculated between means using (Costat program 6.3 for windows) ${ }^{(32)}$.

\section{RESULTS}

\section{-Serum antioxidant enzymes:}

Table (1) showed significant differences $(p<0.001)$ in serum catalase and SOD levels between all groups after both $1^{\text {st }}$ and $2^{\text {nd }}$ months of the experimental period, while serum GPx level showed significant differences at $(\mathrm{p}<0.01)$ and $(\mathrm{p}<0.001)$ after $1^{\text {st }}$ and $2^{\text {nd }}$ month respectively.

\section{(1) Catalase}

After both $1^{\text {st }}$ and $2^{\text {nd }}$ months, the $2^{\text {nd }}$ and $4^{\text {th }}$ groups showed significant increases in level of serum catalase compared to control group, while the $3^{\text {rd }}$ group showed a significant decrease. Cholesterol treatment caused a significant decrease in level of serum catalase after $2^{\text {nd }}$ month compared to $1^{\text {st }}$ month.

\section{(2) Superoxide dismutase (SOD)}

After both $1^{\text {st }}$ and $2^{\text {nd }}$ months, the $3^{\text {rd }}$ and $4^{\text {th }}$ groups showed significant decrease and increase in level of serum SOD respectively compared to control and other treated groups. The $4^{\text {th }}, 5^{\text {th }}$ and $6^{\text {th }}$ groups showed significant increases in level of serum SOD after $2^{\text {nd }}$ month compared to $1^{\text {st }}$ month.

(3) Glutathione peroxidase (GPx)

After $1^{\text {st }}$ month, the $3^{\text {rd }}$ and $4^{\text {th }}$ groups showed significant decrease and increase in level of serum GPX respectively compared to control and other treated groups. After $2^{\text {nd }}$ month, the $2^{\text {nd }}$ and $4^{\text {th }}$ groups showed significant increases in level of serum GPX compared to control and other treated groups. The 3rd group showed a significant decrease in level of serum GPX compared to control and $5^{\text {th }}$ groups. Treatment with coconut oil caused a significant increase in level of serum GPX after $2^{\text {nd }}$ month compared to $1^{\text {st }}$ month.

\section{-Serum lipid profile:}

Table (2) showed that there were non significant and significant differences at $(\mathrm{p} \geq 0.05)$ and $(p<0.001)$ in total lipid and significant differences at $(\mathrm{p}<0.01)$ and $(\mathrm{p}<0.001)$ in serum TG, TC and VLDL-C between all groups after $1^{\text {st }}$ and $2^{\text {nd }}$ month of the experimental period respectively, while serum HDL-C and LDL-C showed significant differences at $(\mathrm{p}<0.001)$ after both $1^{\text {st }}$ and $2^{\text {nd }}$ months.

\section{(1) Total lipid (TL)}

After $2^{\text {nd }}$ month, the $3^{\text {rd }}$ and $4^{\text {th }}$ groups showed significant increase and decrease in total lipid respectively compared to control and other treated groups. Treatment with honey caused a significant decrease in total lipid after $2^{\text {nd }}$ month compared to $1^{\text {st }}$ month.

(2) Triglycrides (TG)

After $1^{\text {st }}$ month, compared to control group the $4^{\text {th }}$ group showed a significant decrease in TG. After $2^{\text {nd }}$ month, the $3^{\text {rd }}$ and $4^{\text {th }}$ groups showed significant increase and decrease in TG respectively compared to control and other treated groups. The $3^{\text {rd }}$ group showed a significant increase in TG after $2^{\text {nd }}$ month compared to $1^{\text {st }}$ month.

\section{(3) Total cholesterol (TC)}

After $1^{\text {st }}$ month, the $3^{\text {rd }}$ group showed a significant increase in serum TC compared to control and other treated groups. After $2^{\text {nd }}$ month, compared to control group the $3^{\text {rd }}$ group showed a significant increase in serum TC. The $3^{\text {rd }}$ group showed a significant increase in TC after $2^{\text {nd }}$ month compared to $1^{\text {st }}$ month.

\section{(4) High density lipoprotein cholesterol} (HDL-C)

After both $1^{\text {st }}$ and $2^{\text {nd }}$ months, all treated groups showed significant increases in serum HDL-C compared to control except the $3^{\text {rd }}$ group which showed a non significant change. The $2^{\text {nd }}, 4^{\text {th }}, 5^{\text {th }}$ 
and $6^{\text {th }}$ groups showed significant increases in HDL-C after $2^{\text {nd }}$ month compared to $1^{\text {st }}$ month.

(5) Low density lipoprotein cholesterol (LDL-C)

After both $1^{\text {st }}$ and $2^{\text {nd }}$ months, all treated groups showed significant decreases in LDL-C compared to control group except the $3^{\text {rd }}$ group which showed a significant increase. Treatment with coconut oil caused a significant decrease in LDL$\mathrm{C}$ after $2^{\text {nd }}$ month compared to $1^{\text {st }}$ month, while cholesterol treatment caused a significant increase.

\section{(6) Very low density lipoprotein cholesterol} (VLDL-C)

After $1^{\text {st }}$ month, compared to control group the $4^{\text {th }}$ group showed a significant decrease in VLDL-C. After $2^{\text {nd }}$ month, the $3^{\text {rd }}$ and $4^{\text {th }}$ groups showed significant increase and decrease in VLDL-C respectively compared to control and other treated groups. The $3^{\text {rd }}$ group showed a significant increase in VLDL-C after $2^{\text {nd }}$ month compared to $1^{\text {st }}$ month. 
Table (1): Effect of administration of $20 \%$ honey $(1 \mathrm{ml} /$ rat by gastric intubation for one and two months) on serum catalase, superoxide dismutase and glutathione peroxidase in male albino rats treated with cholesterol $(400 \mathrm{mg} / \mathrm{kg}$ b.w by gastric intubation dissolved in $0.5 \mathrm{ml}$ coconut oil $)$ with or before honey treatments.

\begin{tabular}{|c|c|c|c|c|c|c|}
\hline \multirow[t]{2}{*}{ Rat groups } & \multicolumn{2}{|c|}{$\begin{array}{l}\text { Catalase } \\
(\mathrm{mmol} / \mathrm{l})\end{array}$} & \multicolumn{2}{|c|}{$\begin{array}{c}\text { Superoxide dismutase (SOD) } \\
(\mathrm{u} / \mathrm{l})\end{array}$} & \multicolumn{2}{|c|}{$\begin{array}{c}\text { Glutathione peroxidase (GPX) } \\
\text { (ng/ml) }\end{array}$} \\
\hline & $1^{\text {st }}$ month & $2^{\text {nd }}$ month & $1^{\text {st }}$ month & $2^{\text {nd }}$ month & $\mathbf{1}^{\text {st }}$ month & $2^{\text {nd }}$ month \\
\hline Control & $55.61 \pm 0.88^{\mathrm{c} \mathrm{A}}$ & $\overline{58.53 \pm 1.77^{\mathrm{cA}}}$ & $49.67 \pm 0.33^{\mathrm{bA}}$ & $51.33 \pm 0.67^{\mathrm{bA}}$ & $24.50 \pm 0.49^{\mathrm{bA}}$ & $25.00 \pm 1.15^{\mathrm{bA}}$ \\
\hline Coconut oil & $62.43 \pm 1.44^{\mathrm{a}, \mathrm{b} \mathrm{A}}$ & $67.01 \pm 1.05^{\mathrm{a}, \mathrm{b} \mathrm{A}}$ & $48.33 \pm 0.87^{\mathrm{b} \mathrm{A}}$ & $51.81 \pm 1.59^{\mathrm{b} \mathrm{A}}$ & $24.42 \pm 0.47^{\mathrm{b} \mathrm{B}}$ & $28.11 \pm 0.55^{\mathrm{aA}}$ \\
\hline Cholesterol & $47.75 \pm 0.63^{\mathrm{dA}}$ & $41.90 \pm 1.02^{\mathrm{dB}}$ & $43.67 \pm 0.33^{\mathrm{c} \mathrm{A}}$ & $42.00 \pm 0.87^{\mathrm{c} \mathrm{A}}$ & $20.67 \pm 0.67^{\mathrm{cA}}$ & $20.81 \pm 1.34^{\mathrm{c} \mathrm{A}}$ \\
\hline Honey & $66.00 \pm 3.05^{\mathrm{aA}}$ & $71.80 \pm 0.92^{\mathrm{aA}}$ & $53.62 \pm 0.69^{\mathrm{a} B}$ & $61.66 \pm 1.20^{\mathrm{aA}}$ & $28.33 \pm 0.88^{\mathrm{a} \mathrm{A}}$ & $30.06 \pm 0.12^{\mathrm{a} \mathrm{A}}$ \\
\hline Cholesterol and honey & $57.17 \pm 2.68^{\mathrm{b}, \mathrm{c} \mathrm{A}}$ & $61.80 \pm 0.76^{\mathrm{b}, \mathrm{c} \mathrm{A}}$ & $49.77 \pm 0.39^{\mathrm{b} \mathrm{B}}$ & $52.56 \pm 0.33^{\mathrm{b} \mathrm{A}}$ & $24.33 \pm 0.67^{\mathrm{bA}}$ & $24.03 \pm 0.05^{\mathrm{b} \mathrm{A}}$ \\
\hline $\begin{array}{c}\begin{array}{c}\text { Cholesterol before } \\
\text { honey }\end{array} \\
\end{array}$ & $56.16 \pm 1.52^{\mathrm{cA}}$ & $62.18 \pm 3.70^{\mathrm{b}, \mathrm{c} \mathrm{A}}$ & $48.69 \pm 0.87^{\mathrm{b} \mathrm{B}}$ & $53.00 \pm 0.57^{\mathrm{b} \mathrm{A}}$ & $25.00 \pm 1.15^{\mathrm{bA}}$ & $23.29 \pm 0.95^{\mathrm{b}, \mathrm{cA}}$ \\
\hline P-value & $* * *$ & $* * *$ & **** & $* * *$ & $* *$ & $* * *$ \\
\hline
\end{tabular}

Values are expressed as means \pm standard errors for seven determinations

abcd= values in same column with different small letters are significantly different at $(\mathrm{P}<0.05)$.

$\mathrm{AB}=$ values in same row with different capital letters are significantly different at $(\mathrm{P}<0.05)$.

$* *$ significant difference between all groups at $\mathrm{P}<0.01$

$* * *=$ significant difference between all groups at $\mathrm{P}<0.001$ 
Table (2): Effect of administration of $20 \%$ honey $(1 \mathrm{ml} / \mathrm{rat}$ by gastric intubation for one and two months) on serum lipid profile in male albino rats treated with cholesterol $(400 \mathrm{mg} / \mathrm{kg} \mathrm{b.w}$ by gastric intubation dissolved in $0.5 \mathrm{ml}$ coconut oil ) with or before honey treatments.

\begin{tabular}{|c|c|c|c|c|c|c|c|c|c|c|c|c|}
\hline \multirow[t]{2}{*}{ Parameters } & \multicolumn{2}{|c|}{$\begin{array}{l}\text { Total lipid } \\
\text { (mg/dl) }\end{array}$} & \multicolumn{2}{|c|}{$\begin{array}{c}\text { Triglycerides TG } \\
\text { (mg/dl) }\end{array}$} & \multicolumn{2}{|c|}{$\begin{array}{c}\text { Total cholesterol TC } \\
\text { (mg/dl) }\end{array}$} & \multicolumn{2}{|c|}{$\begin{array}{c}\text { HDL- cholesterol } \\
\text { (mg/dl) }\end{array}$} & \multicolumn{2}{|c|}{$\begin{array}{c}\text { LDL- cholesterol } \\
\text { (mg/dl) }\end{array}$} & \multicolumn{2}{|c|}{$\begin{array}{c}\text { VLDL- cholesterol } \\
\text { (mg/dl) }\end{array}$} \\
\hline & $\begin{array}{c}1^{\text {st }} \\
\text { month }\end{array}$ & $\begin{array}{c}2^{\text {nd }} \\
\text { month }\end{array}$ & $\begin{array}{c}1^{\text {st }} \\
\text { month }\end{array}$ & $\begin{array}{c}2^{\text {nd }} \\
\text { month }\end{array}$ & $\begin{array}{c}1^{\text {st }} \\
\text { month }\end{array}$ & $\begin{array}{c}2^{\text {nd }} \\
\text { month }\end{array}$ & $\begin{array}{c}1^{\text {st }} \\
\text { month }\end{array}$ & $\begin{array}{c}2^{\text {nd }} \\
\text { month }\end{array}$ & $\begin{array}{c}1^{\text {st }} \\
\text { month }\end{array}$ & $\begin{array}{c}2^{\text {nd }} \\
\text { month }\end{array}$ & $\begin{array}{c}1^{\text {st }} \\
\text { month }\end{array}$ & $\begin{array}{c}2^{\text {nd }} \\
\text { month }\end{array}$ \\
\hline Control & $\begin{array}{l}713.75 \pm \\
8.50^{\mathrm{A}}\end{array}$ & $\begin{array}{l}725.00 \pm \\
10.41^{\mathrm{b} \mathrm{A}}\end{array}$ & $\begin{array}{l}113.75 \pm \\
2.52^{\mathrm{a}, \mathrm{b} \mathrm{A}}\end{array}$ & $\begin{array}{c}106.00 \pm \\
1.96^{\mathrm{b} \mathrm{A}}\end{array}$ & $\begin{array}{l}73.25 \pm \\
2.01^{\mathrm{b} \mathrm{A}}\end{array}$ & $\begin{array}{c}77.00 \pm \\
1.22^{\mathrm{b}, \mathrm{c} \mathrm{A}}\end{array}$ & $\begin{array}{l}25.25 \pm \\
2.29^{\mathrm{b} A}\end{array}$ & $\begin{array}{l}28.00 \pm \\
0.82^{\text {b A }}\end{array}$ & $\begin{array}{l}25.24 \pm \\
0.81^{\text {b A }}\end{array}$ & $\begin{array}{l}27.80 \pm \\
0.67^{\text {b A }}\end{array}$ & $\begin{array}{c}22.75 \pm \\
0.50^{\mathrm{a}, \mathrm{b} \mathrm{A}}\end{array}$ & $\begin{array}{l}21.20 \pm \\
0.39^{\mathrm{b} \mathrm{A}}\end{array}$ \\
\hline Coconut oil & $\begin{array}{l}708.75 \pm \\
8.26^{\mathrm{A}}\end{array}$ & $\begin{array}{l}710.00 \pm \\
8.16^{\mathrm{bA}}\end{array}$ & $\begin{array}{l}114.00 \pm \\
2.34^{\mathrm{a}, \mathrm{b} \mathrm{A}}\end{array}$ & $\begin{array}{l}111.00 \pm \\
1.29^{\mathrm{b} \mathrm{A}}\end{array}$ & $\begin{array}{l}76.00 \pm \\
2.16^{\mathrm{b} \mathrm{A}}\end{array}$ & $\begin{array}{l}80.25 \pm \\
0.85^{\text {b A }}\end{array}$ & $\begin{array}{l}34.00 \pm \\
1.47^{\mathrm{a}}\end{array}$ & $\begin{array}{l}40.75 \pm \\
1.31^{\text {a A }}\end{array}$ & $\begin{array}{l}19.20 \pm \\
0.39^{\mathrm{c} A}\end{array}$ & $\begin{array}{l}17.30 \pm \\
0.34^{\mathrm{cB}}\end{array}$ & $\begin{array}{c}22.80 \pm \\
0.47^{\mathrm{a}, \mathrm{b} \mathrm{A}}\end{array}$ & $\begin{array}{l}22.20 \pm \\
0.25^{\mathrm{b} A}\end{array}$ \\
\hline Cholesterol & $\begin{array}{l}730.00 \pm \\
14.72^{\mathrm{A}}\end{array}$ & $\begin{array}{l}755.00 \pm \\
13.23^{\mathrm{a} A}\end{array}$ & $\begin{array}{l}111.75 \pm \\
1.18^{\mathrm{b} \mathrm{B}}\end{array}$ & $\begin{array}{l}129.75 \pm \\
1.25^{\mathrm{aA}}\end{array}$ & $\begin{array}{l}84.25 \pm \\
1.11^{\mathrm{a} \mathrm{B}}\end{array}$ & $\begin{array}{l}91.25 \pm \\
1.75^{\text {a A }}\end{array}$ & $\begin{array}{l}28.75 \pm \\
0.63^{\mathrm{b} A}\end{array}$ & $\begin{array}{l}25.92 \pm \\
0.97^{\mathrm{b} \mathrm{A}}\end{array}$ & $\begin{array}{l}33.15 \pm \\
1.17^{\mathrm{a}}\end{array}$ & $\begin{array}{l}39.37 \pm \\
2.06^{\mathrm{a} \mathrm{A}}\end{array}$ & $\begin{array}{l}22.35 \pm \\
0.23^{\mathrm{b}} \mathrm{B}\end{array}$ & $\begin{array}{l}25.95 \pm \\
0.25^{\text {a } \mathrm{A}}\end{array}$ \\
\hline Honey & $\begin{array}{l}707.50 \pm \\
4.67^{\mathrm{A}}\end{array}$ & $\begin{array}{l}650.00 \pm \\
4.08^{\mathrm{c} \mathrm{B}}\end{array}$ & $\begin{array}{l}102.50 \pm \\
3.20^{\mathrm{c} \mathrm{A}}\end{array}$ & $\begin{array}{l}96.00 \pm \\
2.31^{\mathrm{c} \mathrm{A}}\end{array}$ & $\begin{array}{l}74.25 \pm \\
0.48^{\mathrm{b} \mathrm{A}}\end{array}$ & $\begin{array}{l}74.50 \pm \\
0.87^{\mathrm{c} A}\end{array}$ & $\begin{array}{l}37.00 \pm \\
1.22^{\mathrm{a} B}\end{array}$ & $\begin{array}{l}38.50 \pm \\
2.06^{\mathrm{a} \mathrm{A}}\end{array}$ & $\begin{array}{l}16.75 \pm \\
0.54^{\mathrm{c} A}\end{array}$ & $\begin{array}{l}16.80 \pm \\
0.80^{\mathrm{c} \mathrm{A}}\end{array}$ & $\begin{array}{l}20.50 \pm \\
0.64^{\mathrm{c} A}\end{array}$ & $\begin{array}{l}19.20 \pm \\
0.46^{\mathrm{cA}}\end{array}$ \\
\hline $\begin{array}{c}\text { Cholesterol and } \\
\text { honey }\end{array}$ & $\begin{array}{l}712.50 \pm \\
4.78^{\mathrm{A}}\end{array}$ & $\begin{array}{c}720.00 \pm \\
8.16^{\mathrm{b} \mathrm{A}}\end{array}$ & $\begin{array}{c}120.25 \pm \\
2.05^{\mathrm{aA}}\end{array}$ & $\begin{array}{l}110.50 \pm \\
3.50^{\mathrm{b} \mathrm{A}}\end{array}$ & $\begin{array}{l}76.50 \pm \\
1.93^{\mathrm{b} \mathrm{A}}\end{array}$ & $\begin{array}{l}78.50 \pm \\
0.50^{\mathrm{b} A}\end{array}$ & $\begin{array}{l}33.25 \pm \\
1.37^{\mathrm{a}}\end{array}$ & $\begin{array}{l}37.25 \pm \\
0.25^{\mathrm{a} A}\end{array}$ & $\begin{array}{l}19.20 \pm \\
0.63^{\mathrm{cA}}\end{array}$ & $\begin{array}{l}19.15 \pm \\
0.95^{\mathrm{c} \mathrm{A}}\end{array}$ & $\begin{array}{l}24.05 \pm \\
0.41^{\mathrm{a}} \mathrm{A}\end{array}$ & $\begin{array}{l}22.10 \pm \\
0.70^{\mathrm{b} \mathrm{A}}\end{array}$ \\
\hline $\begin{array}{c}\text { Cholesterol before } \\
\text { honey }\end{array}$ & $\begin{array}{c}710.00 \pm \\
7.07^{\mathrm{A}}\end{array}$ & $\begin{array}{c}717.50 \pm \\
4.33^{\mathrm{b} \mathrm{A}}\end{array}$ & $\begin{array}{l}108.50 \pm \\
2.90^{\mathrm{b}, \mathrm{c}} \mathrm{A}\end{array}$ & $\begin{array}{c}110.48 \pm \\
3.60^{\mathrm{b} \mathrm{A}}\end{array}$ & $\begin{array}{l}75.25 \pm \\
2.28^{\mathrm{b} \mathrm{A}}\end{array}$ & $\begin{array}{l}78.47 \pm \\
0.37^{\text {b A }}\end{array}$ & $\begin{array}{l}35.00 \pm \\
0.82^{\mathrm{a}}\end{array}$ & $\begin{array}{l}37.75 \pm \\
0.75^{\text {a A }}\end{array}$ & $\begin{array}{l}18.55 \pm \\
1.28^{\mathrm{c} A}\end{array}$ & $\begin{array}{l}18.65 \pm \\
0.45^{\mathrm{c} \mathrm{A}}\end{array}$ & $\begin{array}{c}21.70 \pm \\
0.58^{\mathrm{b}, \mathrm{c} \mathrm{A}}\end{array}$ & $\begin{array}{l}22.10 \pm \\
0.66^{\text {b A }}\end{array}$ \\
\hline P-value & N.S & $* * *$ & $* *$ & $* * *$ & $* *$ & $* * *$ & $* * *$ & $* * *$ & $* * *$ & $* * *$ & $* *$ & $* * *$ \\
\hline
\end{tabular}

Values are expressed as means \pm standard errors for seven determinations

abcd = values in same column with different small letters are significantly different at $(\mathrm{P}<0.05)$.

$\mathrm{AB}=$ values in same row with different capital letters are significantly different at $(\mathrm{P}<0.05)$.

N.S = non significant difference between all groups at $\mathrm{P} \geq 0.05$

$* *$ significant difference between all groups at $\mathrm{P}<0.01$

$* * *=$ significant difference between all groups at $\mathrm{P}<0.001$ 


\section{DISCUSSION}

Oxidative stress is the condition in which the cellular antioxidant defences system is insufficient to keep the levels of reactive oxygen species (ROS) low in the body. ROS are unstable molecules and prone to attack cellular function cells and cause oxidative damage to lipid, protein and DNA. Steinberg and Witztum ${ }^{(33)}$ reported that antioxidant supplementation gave therapeutic effects towards subjects with high oxidative stress. The action of honey to prevent oxidative damage might be due to its phenolic and non phenolic antioxidant content or indirectly through the action of catalase activity in reducing hydrogen peroxide.

In the present study, coconut oil is used as a solvent of cholesterol. Treatment with coconut oil caused significant increases in catalase (after one and two months) and GPx (aftert two months). These increases may be due to that coconut oil improve antioxidant defense. These results agreed with those of Nevin and Rajamohan ${ }^{(34)}$ and Nagaraju and Belur ${ }^{(35)}$. They reported that coconut oil helped in increasing the activity of antioxidant enzymes such as SOD, GPx and catalase by lowering the steady state of superoxide anion $\left(\mathrm{O}_{2}^{-}\right)$.

Cholesterol administration induced significant decreases in antioxidant enzymes (aftert one and two months). These decreases may be attributed to hypercholesterolemia which increases oxidative stress and lipid peroxidation. These results agreed with those of Kojda and Harrison (36) and Gewalting and Kojda ${ }^{(37)}$. They found that a variety of cardiovascular diseases which result from hypercholesterolemia associated with vascular oxidative stress due to increased production of superoxide anion $\left(\mathrm{O}_{2}^{-}\right)$ and a decrease in antioxidant enzymes. Heibashy ${ }^{(5)}$; Shah and Channon ${ }^{(38)}$ and Hayashi et al. ${ }^{(39)}$ stated that cholesterol administration may cause an increase in production of superoxide anion $(\mathrm{O}$ ${ }_{2}$ ) in arteries and increased the expression of oxidation-sensitive gene which lead to decreased activity of antioxidant enzyme thus antioxidant defense impaired.

Treatment with honey caused significant increases in antioxidant enzymes (after one and two months). The antioxidant effect of honey may be attributed to its constituents of the most important antioxidant trace elements and to the antioxidant activity of its flavonoid compounds. Therefore, honey has been suggested to be able to decrease the nitric oxide and lipid peroxidation (40). Machlin and Bendich ${ }^{(41)}$ explained that honey constituents include the antioxidant trace elements iron, zinc and selenium which are essential cofactors for the enzymatic antioxidant defense system represented by catalase, superoxide dismutase and glutathione peroxidase. Increased GPx might be due to the presence of selenium in honey ${ }^{(42)}$. Selenium acts as a cofactor for GPx activity. Thus supplementation of honey might increase the selenium availability in the body and thus increase GPx activity.

Treatment with cholesterol and honey caused significant increases in antioxidant enzymes (after one and two months) compared to cholesterol treated group. These increases may be attributed to the antioxidant properties of honey against the oxidative stress induced by hypercholesterolemia. These results agreed with those of Abdel-Moneim and Ghafeer ${ }^{(43)}$ who found that reduced glutathione peroxidase activity was recovered after coadministration of honey with cadmium in liver and kidney tissues, which in turn destructs the lipid peroxidase ${ }^{(44)}$. An increase in the dose of honey will increase the level of antioxidant activity ${ }^{(45)}$. This confirm that honey increase antioxidant activity and able to protect from oxidative stress.

Treatment with cholesterol before honey caused significant increases in catalase, SOD (after one and two months) and GPx (after one month) compared to cholesterol treated group. These increases may be attributed to the protective antioxidant activity of honey. This protective effect of honey may be attributed to the biologically active compounds such as vitamins, flavonoids, and antioxidants that work together to scavenge free radicals ${ }^{(46)}$. Exogenous antioxidants such as ginger, honey, Chlorella vulgaris, vitamin $\mathrm{E}$, and vitamin $\mathrm{C}$ may help in eradicating the large amount of ROS ${ }^{(21)}$.

Treatment with coconut oil caused a significant increase and decrease in HDL-C and LDL-C respectively (after one and two months). These results agreed with the reported results of Mensink and katan ${ }^{(47)}$ and Tebib et al. ${ }^{(48)}$.The increase of HDL-C level may help in transport of cholesterol from peripheral tissue to liver, thus TC level kept constant. Coconut oil may cause an increase in lecithin cholesterol acyltransferase (LCAT) level which associated with increase in HDL-C concentration (7). In addition Nevin and Rajamohan ${ }^{(49)}$ reported that virgin coconut oil reduced TC and TG levels and prevent LDL oxidation.

Cholesterol treatment induced significant increases in TC, LDL-C (after one and two months) and total lipid, TG and VLDL-C (after two months). Elevation of serum LDL-C may due 
to that cholesterol lead to down regulation of LDL-receptors thus LDL cannot influx into cells and its serum level raise. These results agreed with Nanami et al. ${ }^{(50)}$; Heibashy (5) and Zulet et al. ${ }^{(51)}$. They reported that diet rich in cholesterol and saturated fatty acid caused down regulation in LDL receptor in rats. Increased VLDL-C level significantly may be due to that the oil increased lipoprotein synthesis in liver and VLDL, the major lipoprotein synthesized. These results agreed with Driscoll et al. ${ }^{(52)}$ and Fungwe et al. ${ }^{(53)}$ who reported increases in plasma TG and hepatic lipid in ginea pigs fed cholesterol in chow diets containing corn or coconut oil and in rabbits received coconut oil. Increased VLDL-C may be attributed to decreased lipoprotein lipase activity (54)

Treatment with honey caused significant decreases in TG, LDL-C, VLDL-C (after one and two months) and total lipid (after two months). These results agreed with those of Luka et al. ${ }^{(17)}$ who found that feeding honey solution to rats increased their serum HDL-C concentration while the serum LDL-C concentration decreased. The decrease in serum LDL-cholesterol concentration could be due to the stimulation of the LDLreceptors (apo B-100, E) causing increase up-take of LDL by the liver and extra hepatic tissues with consequent lowering of plasma cholesterol ${ }^{(55)}$. The decreased serum LDL-cholesterol concentration could also be a result of increased LDL catabolism via receptor independent pathways like the scavenger pathway which is not regulated (56). These results also agreed with Yaghoobi et al. ${ }^{(57)}$ who reported that natural honey decreased total cholesterol and LDL-C in overweight healthy and overweight hyperlipidemic subjects. Also the decrease of LDL-C level may be attributed to the antioxidant properties of honey. Oxidative modification of LDL plays an important role in the development of atherosclerosis ${ }^{(58)}$. Antioxidants that prevent LDL from oxidation could attenuate the development of atherosclerosis.

Rats treated with cholesterol and honey or cholesterol before honey showed significant increases and decreases in HDL-C and LDL-C respectively (after one and two months) compared to control and cholesterol treated groups. These results agreed with those of Alagwu (59) who found that chronic honey intake caused intestinal smooth muscle relaxation and reduced intestinal transit as well as increased high density lipoproteins (HDL) in albino rats. Increased plasma HDL is reported to increase cholesterol transport from the plasma and peripheral tissues to the liver ${ }^{(60)}$ so the plasma cholesterol level decreased.

Al-Waili ${ }^{(61)}$ confirmed that honey increased the levels of antioxidants and this effect might be attributed to the composition of honey, which contains many nutrient elements and antioxidants as vitamin $\mathrm{C}$, which is a potent antioxidant agent.

In conclusion, honey administration with or after hypercholesterolemic induction significantly increased antioxidant enzymes and improved lipid profile so can used as a perfect antioxidant therapy for treating and protecting the cardiovascular heart diseases.

\section{REFERENCES}

(1) Ross, R. (1993): The pathogenesis of atherosclerosis: A perspective for the 1990s. Nature, 362: 801-809.

(2) Lee, R.T. and Libby, P. (1997): The unstable atheroma. Arterioscler. Thrombo. Vasc. Biol., 17: 1859-1867.

(3) Reddy, K.G.; Nair, R.N.; Sheehan, H.M. and Hodgson, J.M. (1994): Evidence that selective endothelial dysfunction may occure in the absence of angiographic or ultrasound atherosclerosis in patients with risk factors for atherosclerosis. J. Am. Coll. Cardiol., 23: 833-843.

(4) Anila, L. and Vijayalakshmi, N.R. (2003): Antioxidant action of flavonoids from Mangifera indica and Emblica officinalis in hypercholesterolemic rats. Food Chem., 83: 569-574.

(5) Heibashy, M.A. (2000): Hypolipidimia effect of taurine and L- carnine on rats fed a high cholesterol diet. J. Union. Arab. Biol. Cairo, 14: 11-23.

(6) Salem, M.M. and Zaahkouk, S.A. (2000): Effect of high fat and protein diet on some physiological parameters related to lipid and protein metabolism in albino rats. J. Egypt. Ger. Soc. Zool., 33: 279-290.

(7) Nevin, K.G. and Rajamohan, T. (2004): Beneficial effect of virgin coconut oil on lipid parameters and in vitro LDL oxidation. Clin. Chem., 37: 830-835.

(8) Perez, E.; Rodriguez-Malaver, A.J. and Vit, P. (2006): Antioxidant capacity of Venezuelan honey in wistar rat homogenates. J. Med. Food, 9: 510-516.

(9) Mohammadzadeh, S.; Sharriatpanahi, M.; Hamedi, M.; Amanzadeh, Y.; Ebrahimi, S. S. E., and Ostad, S. N. (2007): Antioxidant power of Iranian propolis extract. Food Chem., 103: 729-733. 
(10) Khan, M. M. (1974): The translation of meaning of Sahih Albukhari Al-Madina AlManawara Islamic University, 7: 395-453.

(11) Postmes, T.; Vande Bogaard, A. E. and Hazen, M. (1993): Honey for wounds, ulcers and skin graft preservation. Lancet, 31:756757.

(12) Fiorani M; Accorsi A; Blasa M; Diamantini $G$ and Piatti E. (2006): Flavonoids from Italian multifloral honey reduce the extracellular ferricyanide in human red blood cells. J. Agric. Food Chem., 54: 8328-8334.

(13) Bilsel,Y.; Bugra, D.; Yamaner, S.; Bulut, T.; Cevikbas, U.; Turkoglu, U. (2002): Could honey have a place in colitis therapy? Digestive Surgery, 29: 306-312.

(14) Walderhaug, M. (2001): US FDA Center for Food Safety and Applied Nutrition's Foodborne Pathogenic Microorganisms and Natural Toxins Handbook. "Grayanotoxin" Chapter 14.

(15) Omotayo, E. O.; Gurtu, S.; Sulaiman, S.A.; Ab Wahab, M.S.; Sirajudeen, K.N.S. and Md. Salleh, M.S. (2010): Hypoglycemic and antioxidant effects of honey supplementation in streptozotocin-induced diabetic rats. Int. J. Vitam. Nutr. Res., 80: $74-82$.

(16) Bahrami, M.; Ataie-Jafari, A.; Hosseini, S.; Foruzanfar, M.H.; Rahmani, M. and Pajouhi, M. (2009): Effects of natural honey consumption in diabetic patients: an 8-week randomized clinical trial. Int. J. Food Sci. Nutr., 60: 618-26.

(17) Luka, C. D.; Idoko, K. M. and Jawonisi, I. O. (2010): Effect of honey on albino rats fed with high lipid diet. J. Medic.Tropics, 12: 3336.

(18) Alagwu, E.A.; Okwara, J.E.; Nneli, R.O. and Osim, E.E. (2011): Effect of honey intake on serum cholesterol, triglycerides and lipoprotein levels in albino rats and potential benefits on risks of coronary heart disease. Niger. J. Physiol. Sci. 26: $161-165$.

(19) Nasrolahi, O.; Heidari, R.; Rahmani, F. and Farokhi, F. (2012): Effect of natural honey from Ilam and metformin for improving glycemic control in streptozotocin-induced diabetic rats. Avicenna. J. Phytomed. 2: 212221.

(20) Abdulrhman, M.M.; El-Hefnawy, M.H.; Aly, R.H.; Shatla, R.H.; Mamdouh, R.M.; Mahmoud, D.M. and Mohamed, W.S. (2013): Metabolic effects of honey in type 1 diabetes mellitus: a randomized crossover pilot study. J. Med. Food. 16: 66-72.
(21) Abdul Sani, N.F.; Belani, L.K.; Sin, C.P.; Abdul Rahman, S.N.A.; Das, S.; Chi, T.Z.; Makpol, S. and Yusof, Y.A.M. (2014): effect of the combination of gelam honey and ginger on oxidative stress and metabolic profile in streptozotocin-induced diabetic sprague-dawley rats. BioMed. Res. Intern. Vol., (2014) ID160695: 9.

(22) Samat, S.; Nor, N.A.M.; Hussein, F.N. and Ismail, W.I.W. (2014): Effects of gelam and acacia honey acute administration on some biochemical parameters of sprague dawley rats. BMC comple. Altern. med., 14: 146.

(23) Dubey, A.K.; Devi, A.; Kutty, G. and Shankar, R.P. (2005): Hypolipidemic activity of Ginkgo biloba extract, EGb 761 in hypercholesterolemic wistar rats. Iran. J. pharmacol. Therapeu., 41: 9-12.

(24) Syazana, N.S.; Hashida, N.H.; Majid, A.M.; Durriyyah Sharifah, H.A. and Kamaruddin, M.Y. (2011): Effect of gelam honey on sperm quality and testis of rat. Sains Malaysiana, 40: 1243-1246.

(25) Luck, H. (1974): Methods in Enzymatic Analysis. $2^{\text {nd }}$ ed., New York: Bergmeyer, Academic Press., 805.

(26) Kakkar, P.; Das,B. and Viswanathan, P.N. (1984): A modified spectrophotometric assay of superoxide dismutase. Indian J. Biochem. Biophys., 21: 130-132.

(27) Reddy, K.P.; Subhani,S.M.; Khan, P.A. and Kumar, K.B.(1995): Effect of light and benzyladenine on dark treated growing rice leaves-changes in peroxidase activity. Plant cell physiol., 26: 987-994.

(28) Zolliner, N. and Kirsch, K. (1962): Microdetermination of lipids by the sulphophosphovanillin reaction. Z. Ges. Exp. Med., 135: 545-61.

(29) Trinder, P. (1969): Enzymatic method of glucose estimation. Ann. Clin. Biochem., 6: 24-33.

(30) Meiattini, F.; Prencipe, L.; Bardelli, F.; Giannini, G. and Tarli, P. (1979): The 4hydroxybenzoate / 4-aminophenazone chromogenic system used in the enzymic determination of serum cholesterol. Clin. Chem., 24: 2161-2165.

(31) Friedewald, W.T.; Levy, R.I. and Fredrickson, D.S. (1972): Estimation of the concentration of low-density lipoprotein cholesterol in plasma, without use of the preparative ultracentrifuge. Clin. Chem., 18:499-502. 
(32) COHORT SOFTWARE (2005): Costat program. V. 6. (780 lighthouse, Ave. PMB 320, Monterey, CA, USA).

(33) Steinberg, D. and Witztum, J.L. (2000): Is the oxidative modification hypothesis relevant to human atherosclerosis? Circulation, 105: 2107-2111.

(34) Nevin, K.G. and Rajamohan, T. (2006): Virgin coconut oil supplemented diet increased the antioxidant status in rats. Food. Chem., 99: 260-266.

(35) Nagaraju, A. and Belur, L.R. (2008): Rats fed blended oils containing coconut oil with ground nut oil or olive oil showed an enhanced activity of hepatic antioxidant enzymes and a reduction in LDL- oxidation. Food. Chem., 108: 950-957.

(36) Kojda, G. and Harrison, D.G. (1999): Interaction between $\mathrm{NO}$ and reactive oxygen species: patho-physiological important in atherosclerosis, hypertension, diabetes and heart failure. Cardiovasc. Res., 43: 562-571.

(37) Gewalting, M.T. and Kojda, G. (2002): Vasoprotection by nitric oxide: mechanisms and therapeutic potential. Cardiovasc. Res., 55: 250-260.

(38) Shah, A.M. and Channon, K.M. (2004): Free radicals and redox signaling in cardiovascular disease. Hear., 18: 872-879.

(39) Hayashi, T.; Satio, A.; Okuno, S.; FerrandDrake, M.; Dodd, R.L. and Chan, P.H. (2005): Damage to the endoplasmic reticulum and activation of apoptotic machinery by oxidative stress in ischemic neurons. J. Cereb. Bloo. Flow. Metab., 25: 41-53.

(40) Rosenblat, G.; Angonnet, S. and Goroshit, A. (1997): Antioxidant properties of honey produced by bees fed with medical plant extracts. Bee-products: PropertiesApplications, and Apitherapy, 49: 49- 55.

(41) Machlin, I.K. and Bendich, A. (1987): Free radical tissue damage: protective role of antioxidant nutrients. Free Radic Biol. Med., 6: 441-445.

(42) Costa-Silva F.; Maia, M.; Matos, C.C.; Calçada, E.; Barros, A.I.R.N.A. and Nunes, F.M. (2011): Selenium content of Portuguese unifloral honeys. J. Food Comp. Anal., 24: 351-355.

(43) Abdel-Moneim, W.M. and Ghafeer, H.H. (2007): The potential protective effect of natural honey against cadmium-induced hepatotoxicity and nephrotoxicity. Mansoura J. Forensic Med. Clin. Toxicol., 15: 75-98.
(44) Eaton, D. L.; Stacey N. H.; Wong, K. L. and Klaassan, C. D. (1980): "Dose response effects of various metals on rat liver metallothionein, glutathione, heme oxygenase, and cytochrome p. 450. Toxicol". Appl. Pharmacol., 55: 393-402.

(45) Aljadi, A.M. and Kamaruddin, M.Y. (2004): Evaluation of the phenolic contents and antioxidant capacities of two Malaysian floral honeys. Food Chem., 85: 513-518.

(46) El Rabey, H.A.; Al Seeni, M.N. and AlSolamy, S.M. (2013): Bees' honey protects the liver of male rats against melamine toxicity. BioMed. Res. Intern. Vol., (2013) ID 786051: 8.

(47) Mensink, R.P. and Katan, M.B. (1992): Effect of dietary fatty acids on serum lipids and lipoproteins. A metaanalysis of 27 trials. Arterioscler. Thromb., 12: 911-919.

(48) Tebib, K.; Besancon, P. and Rouanet, J.M. (1994): Dietary grape seed tannins effects lipoprotein lipase and tissue lipids in rats fed hypercholesterolemic diets. J. Nutria., 124: 2451-2457.

(49) Nevin, K.G. and Rajamohan, T. (2008): Influence of virgin coconut oil on blood coagulation factors, lipid levels and LDLoxidation in cholesterol fed Sprague-dawley rats. Euro. J. Clin. Nutri. Metab., 3: 1-8.

(50) Nanami, H.; Oda, H. and Yokogoshi, H. (1996): Antihypercholesteroleic of taurine on streptozotocin-diabetic rats or rats fed a high cholesterol diet. Taurine, 2: 261-568.

(51) Zulet, M.A.; Barber, A.; Garcin, H.; Higueret, P. and Martinez, J.A. (1999): Alternations in carbohydrate and lipid metabolism induced by a diet rich in coconut oil and cholesterol in a rat model. J. Am. Collg. Nutria., 18: 36-42.

(52) Driscoll, D.M.; Mazzone, T.; Matsushima, T and Getz, G.S. (1990): Apoprotein E biosynthesis in the cholesterol-fed guinea pig. Arterioscler. Thromb. Vasc. Biol., 10: 31-39.

(53) Fungwe, T.V.; Cagen, L.M.; Wilcox, H.G. and Heimberg, M. (1992): Regulation of hepatic secretion of very low density lipoprotein by dietary cholesterol. J. Lipi. Res., 33: 179-191.

(54) El-Gendy, A.; Tohamy, A. and El-Zawahry, B. (2000): Cholesterol methionine combination increase the risk of hyperlipidemia and serum glucose in male albino rats. J. Union. Arab. Biol. Cairo, 14: 299-310. 
(55) Maton, A.; Jean, H. and Charles, W.M. (1993): Human Biology and Health. Englewood Cliffs, New Jersey, USA.; Prentice Hall. Pp 386-398.

(56) Robert, K.M.; Daryl, K.G. and Peter, A.M. (1999): Harper's Biochemistry. Lange Medical Publications. New York USA. Pp 160-295.

(57) Yaghoobi, N.; Al Waili, N.; GhayourMobarhan, M.; Parizadeh, S. M. R.; Abasalti, Z.; Yaghoobi, Z.; Yaghoobi, F.; Esmaeili, H.; Kazemi-Bajestani, S. M. R.; Aghasizadeh, R.; Saloom, K. Y. and Ferns, G. A. A. (2008): Natural honey and cardiovascular risk factors; Effects on blood glucose, cholesterol, triacylglycerole, CRP, and body weight compared with sucrose. Sci. world j., 8: 463-469.
(58) Witztum, J. L. and Steinberg, D. (1991): Role of oxidized low density lipoprotein in atherogenesis. J. Clin. Investig., 88: 17851792.

(59) Alagwu, E. A. (2008): Effects of chronic consumption of honey in gastro-intestinal function in rats. Ph.D Thesis in the Department of Physiology, Abia State University, Uturu, Nigeria.

(60) Ganong, W. F. (2003): Review of Medical Physiology. $21^{\text {st }}$ ed. Lange Medical books/Mc Graw-Hill Company Medical Publishing Division. 306-11.

(61) Al-Waili, N.S. (2003): Effects of daily consumption of honey solution on hematological indices and blood levels of minerals and enzymes in normal individuals. J. Med. Food, 6:135-140. 